\title{
URINALYSIS IN DEHYDRATION FEVER
}

\author{
BY
}

\author{
JOHN THOMSON, M.D., D.P.H., D.C.H.
}

(From the Department of Child Life and Health, University of-Edinburgh)

\section{Introduction}

In the course of carrying out a series of observations on renal output and the composition of the urine in the newborn period, two cases of dehydration fever were observed. The observations recorded in these two cases deviate so far from the normal, Thomson (1944), that their separate recording is desirable.

\section{Case Records}

Baby M.-Baby M. was born spontaneously at 1.45 p.m. and weighed $9 \mathrm{lb}$. $2 \frac{1}{2} \mathrm{oz}$. It was the first baby of a young mother aged 22 years. The weight curve was within normal limits and the number of stools passed was not excessive. Under test feeding conditions the baby was put three times to the breast in the first twenty-four.hours, but it obtained no measurable amount of fluid. During this period two separate half-ounce feeds of 5 per cent. glucose in normal saline were given at 12 midnight and 6 a.m. Subsequently the baby was put to the breast at three-hourly intervals, always under test feeding conditions, and was given no further extra fluids except one ounce of sterile water at 3 p.m. during its fourth twenty-four-hour period. A record of the test feeds was kept (table 1).

TABLB 1

BABY M. TEST FEEDS IN OUNCES

\begin{tabular}{|c|c|c|c|c|c|c|c|c|c|}
\hline Day & 1 & 2 & 3 & 4 & 5 & 6 & 7 & 8 & 9 \\
\hline 3.p.m. & - & Nil & Nil & $1 \frac{1}{2}$ & $1 t$ & $1 \frac{1}{2}$ & 2 & $1 \frac{7}{8}$ & $2\}$ \\
\hline 6 p.m. & - & Nil & $\overline{\mathrm{Nil}}$ & $\sqrt{3}$ & 3 & $1 t$ & $2 t$ & $3 \frac{8}{8}$ & 24 \\
\hline 10 p.m. & Nil & Nil & Nil & $1 \frac{1}{2}$ & $2 \frac{1}{2}$ & $1 \frac{9}{8}$ & $1 \frac{1}{2}$ & $2 \frac{1}{8}$ & 28 \\
\hline $\begin{array}{l}12 \text { midn't } \\
6 \text { a.m. }\end{array}$ & $\begin{array}{r}1 \\
\text { g. } \\
\text { g. } \\
\end{array}$ & Nil & $\dot{\bar{t}}$ & $\overline{1}$ & $\overline{38}$ & $\overline{2 t}$ & $\overline{14}$ & $\overline{21}$ & $\overline{2 !}$ \\
\hline 9 a.m. & $\mathrm{Nil}$ & $t$ & Nil & 11 & $1 \frac{1}{2}$ & $1 \frac{1}{4}$ & 2 & $1 z$ & $2 \frac{1}{2}$ \\
\hline 12 noon & Nil & Nil & Nil & $1 t$ & 21 & 18 & $3 t$ & $5 t$ & - \\
\hline Total & 1 & $t$ & $t$ & 68 & $14 t$ & $10 t$ & 128 & 17 & $13 t+$ \\
\hline
\end{tabular}

Using an apparatus described in a previous article, Thomson (1944), the output of urine and time of voiding were continuously recorded. The daily total volume of urine was examined as to its specific gravity, urea, and chloride concentration. These results are shown in tables 2 and 3.

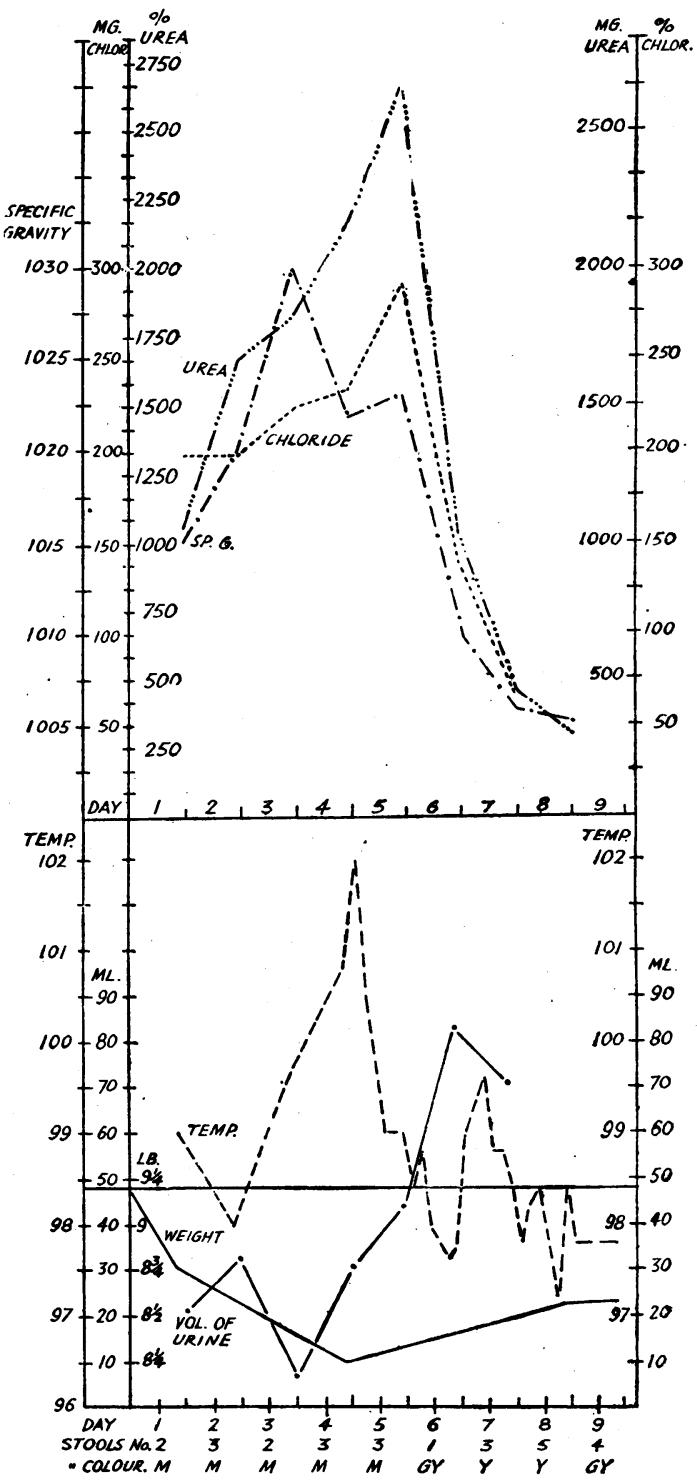

Fig. 1.-Baby $M$. To show weight, temperature, volume of urine output, specific gravity, and urea and chloride concentration of urine. 
TABle 2

BABY M. TIMES OF VOIDING AND VOLUME OF URINE PASSED

\begin{tabular}{|c|c|c|c|c|c|c|c|c|c|c|}
\hline$\underset{1}{\text { Day }}$ & $\begin{array}{r}\text { a.m. } \\
\text { ml. } 9.5 \\
9 \cdot 5\end{array}$ & $\begin{array}{l}10.50 \\
11.5\end{array}$ & & & & & & & $\therefore$ & $\begin{array}{l}\text { Totals } \\
21\end{array}$ \\
\hline 2 & $\begin{array}{r}\text { p.m. } \\
2.30 \\
\text { ml. } \mathbf{7} \cdot 5\end{array}$ & 6.50 & $\begin{array}{l}\text { a.m. } \\
3.50 \\
6\end{array}$ & $\begin{array}{r}8 \\
12\end{array}$ & $\begin{array}{r}11 \\
1\end{array}$ & $\begin{array}{l}\text { p.m. } \\
12.30 \\
2\end{array}$ & & & & 32.5 \\
\hline 3 & $\begin{array}{r}\text { a.m. } \\
5.30 \\
\text { ml. } 1.5\end{array}$ & $\begin{array}{l}\text { p.m. } \\
1.30 \\
4\end{array}$ & \begin{tabular}{|l|}
1.35 \\
1.5
\end{tabular} & & & & & & & 7 \\
\hline 4 & \begin{tabular}{r|} 
p.m. \\
ml. 7.30
\end{tabular} & $\begin{array}{l}8.30 \\
4\end{array}$ & 10.15 & $\left\{\begin{array}{c}11.30 \\
1.5\end{array}\right.$ & $\begin{array}{l}\text { a.m. } \\
1.30 \\
2 \cdot 5\end{array}$ & 5.30 & 7.30 & 5.50 & $\begin{array}{l}\text { p.m. } \\
12.45 \\
6\end{array}$ & 31 \\
\hline 5 & $\begin{array}{c}\text { p.m. } \\
\mathrm{ml}^{4} \mathbf{3}^{-}\end{array}$ & $\begin{array}{l}7 \\
5\end{array}$ & $\begin{array}{l}8.30 \\
36\end{array}$ & & & & & & & 44 \\
\hline 6 & 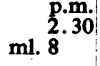 & 8.30 & $\begin{array}{l}9 \\
5\end{array}$ & $\begin{array}{l}1 \\
3\end{array}$ & $\begin{array}{l}1.35 \\
36\end{array}$ & $22^{1.45}$ & & & & 83 \\
\hline 7 & $\begin{array}{l}\text { p.m. } \\
\text { ml. } 39\end{array}$ & $\begin{array}{r}5 \\
17\end{array}$ & $\begin{array}{l}\text { a.m. } \\
9 \\
15\end{array}$ & & & & & & & 71 \\
\hline 8 & $\begin{array}{l}\text { p.m. } \\
\mathbf{m l} .7\end{array}$ & 28 & & & & & & & & \\
\hline
\end{tabular}

Towards the end of the third twenty-four-hour period, and coinciding with a diminution of the urinary output, the baby became irritable and restless, crying frequently and lustily, having parched lips and tongue and a dry hot skin. A temperature of $99 \cdot 6^{\circ} \mathrm{F}$. was recorded, and a four-hourly chart was kept until the pyrexia ceased (fig. 1).

The infant was discharged clinically well and fully breast fed on its tenth day, weighing $8 \mathrm{lb} .9 \mathrm{oz}$.

Baby B.-Baby B. was born at 4.35 p.m. and weighed $6 \mathrm{lb}$. $7 \mathrm{oz}$. It was the spontaneously delivered baby of a 20-year-old primpara. The weight curve approximated to the normal, while the number of stools passed was not excessive, although eight were recorded on the seventh day of life. The baby was put to the breast five times in the first twenty-four hours but obtained no measurable quantity of fluid other than $\frac{1}{4} \mathrm{oz}$. at the $3 \mathrm{p} . \mathrm{m}$. feed. In this instance also regular three-hourly test feeding was carried out and the results are shown in table 4. No fluid other than that obtained at the breast was given.

TABLE 4

BABY B. TEST FEEDS IN OUNCES

\begin{tabular}{|c|c|c|c|c|c|c|c|c|c|c|}
\hline & Day & 1 & 2 & 3 & 4 & 5 & 6 & 7 & 8 & 9 \\
\hline $\begin{array}{r}66 \\
10 \\
6 \\
9 \\
12 \\
3\end{array}$ & $\begin{array}{l}\text { p.m. } \\
\text { p.m. } \\
\text { a.m. } \\
\text { a.m. } \\
\text { noon } \\
\text { p.m. }\end{array}$ & $\begin{array}{l}\overline{\mathrm{Nil}} \\
\mathrm{Nil} \\
\mathrm{Nil} \\
\mathrm{Nil} \\
\mathbf{t}\end{array}$ & 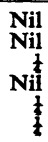 & $\begin{array}{c}\text { Nil } \\
1^{\frac{1}{2}} \\
1 \\
1 \\
1 \frac{1}{1}\end{array}$ & $\begin{array}{l}1 \\
1 \frac{1}{1} \\
1 \frac{1}{8} \\
1 \frac{4}{4} \\
1 \frac{1}{8} \\
1\end{array}$ & $\begin{array}{l}1 \frac{1}{2} \\
2 \\
2 \frac{1}{2} \\
1 \frac{1}{2} \\
1 \frac{1}{4} \\
2 \frac{1}{4}\end{array}$ & $\begin{array}{l}1 \frac{1}{1} \\
2 \frac{5}{4} \\
3 \\
3 \frac{1}{2} \\
1 \frac{8}{4} \\
2\end{array}$ & $\begin{array}{l}3 \\
21 \\
14 \\
3 \\
1 \frac{1}{4} \\
21\end{array}$ & $\begin{array}{l}1 \frac{13}{2} \\
2 \frac{1}{2} \\
2 \frac{1}{4} \\
24 \\
2 \\
2 \frac{8}{4}\end{array}$ & $\begin{array}{l}2 \\
3 t \\
3 \\
3 \\
4 t \\
3\end{array}$ \\
\hline & Total & $t$ & t & $4 \frac{1}{2}$ & $\cdot 8 t$ & $11 \frac{1}{2}$ & $14 \frac{1}{2}$ & 14 & $14 \frac{1}{2}$ & $18 \frac{8}{8}$ \\
\hline
\end{tabular}

As in the previous instance, records were kept of the urinary output and times of voiding, table 5, while the results of urinalysis are given in table 3.

TABLE 3

DAILY VOLUME OF URINE WITH SPECIFIC GRAVITY, CONCENTRATION OF UREA, AND CHLORIDES COMPARED WITH AVERAGE FIGURES. THOMSON (1944)

\begin{tabular}{|c|c|c|c|c|c|c|c|c|c|c|c|c|}
\hline \multirow[b]{2}{*}{ Day } & \multicolumn{3}{|c|}{ Daily output of urine } & \multicolumn{3}{|c|}{ Specific gravity } & \multicolumn{3}{|c|}{$\begin{array}{l}\text { Urea concentration } \\
\text { mg. } \%\end{array}$} & \multicolumn{3}{|c|}{$\begin{array}{l}\text { Chloride concentration } \\
\text { mg. } \%\end{array}$} \\
\hline & $\begin{array}{c}\text { Average } \\
\text { normal } \\
\text { ml. }\end{array}$ & $\begin{array}{l}\text { Baby } \\
\text { M. }\end{array}$ & $\begin{array}{l}\text { Baby } \\
\text { B. }\end{array}$ & Average & $\begin{array}{l}\text { Baby } \\
\text { M. }\end{array}$ & $\begin{array}{l}\text { Baby } \\
\text { B. }\end{array}$ & Average & $\begin{array}{l}\text { Baby } \\
\text { M. }\end{array}$ & $\begin{array}{l}\text { Baby } \\
\text { B. }\end{array}$ & Average & $\begin{array}{l}\text { Baby } \\
\text { M. }\end{array}$ & $\begin{array}{l}\text { Baby } \\
\text { B. }\end{array}$ \\
\hline 1 & $19 \cdot 5$ & 21 & Nil & $1012 \cdot 2$ & 1015 & Nil & 670 & 1060 & Nil & 250 & 198 & Nil \\
\hline 2 & $20 \cdot 6$ & $32 \frac{1}{2}$ & 3 & $1014 \cdot 6$ & 1020 & - & 956 & 1670 & 600 & 194 & 198 & 410 \\
\hline 3 & 36 & 7 & $3 \frac{1}{2}$ & 1013 & 1030 & - & 690 & 1820 & 1710 & 129 & 222 & 139 \\
\hline 4 & $64 \cdot 8$ & 31 & $8 \frac{1}{2}$ & 1010 & 1022 & 1025 & 497 & 2160 & 1990 & 89 & 234 & 151 \\
\hline 5 & $103 \cdot 3$ & 44 & 31 & 1009 & 1023 & .1013 & 324 & 2660 & 1610 & 146 & 292 & 187 \\
\hline 6 & $124 \cdot 5$ & 83 & 59 & $1009 \cdot 2$ & 1010 & 1008 & 286 & 1030 & 860 & 153 & 139 & 91 \\
\hline 7 & $146 \cdot 6$ & 71 & 106 & $1008 \cdot 8$ & 1006 & 1006 & 272 & 470 & 470 & 163 & 67 & 79 \\
\hline 8 & 151 & - & - & 1008 & 1005 & - & 282 & 300 & - & 142 & - & - \\
\hline 9 & $175 \cdot 4$ & - & - & $1007 \cdot 8$ & - & - & 250 & - & - & 122 & - & - \\
\hline
\end{tabular}


As in the case of the first baby, pyrexia with the accompanying clinical signs of dehydration fever became manifest towards the end of the third twenty-four-hour period. A temperature of $99 \cdot 8^{\circ} \mathrm{F}$. was then recorded, and a four-hourly chart was kept until the baby was eight days old and all pyrexia had ceased (fig. 2).



Fig. 2.-Baby B. To show weight, temperature, volume of urine output, specific gravity, and urea and chloride concentration of urine.
The infant was discharged fully breast fed on its thirteenth day when it was $6 \frac{1}{2} \mathrm{oz}$. over its birth weight.

\section{Discussion}

Since Holt (1895) first described this condition the results of investigations by various workers have gradually narrowed down the probable cause to one of dehydration. That dehydration can produce pyrexia has been proven experimentally by Balcar et al. (1919). The literature was surveyed by

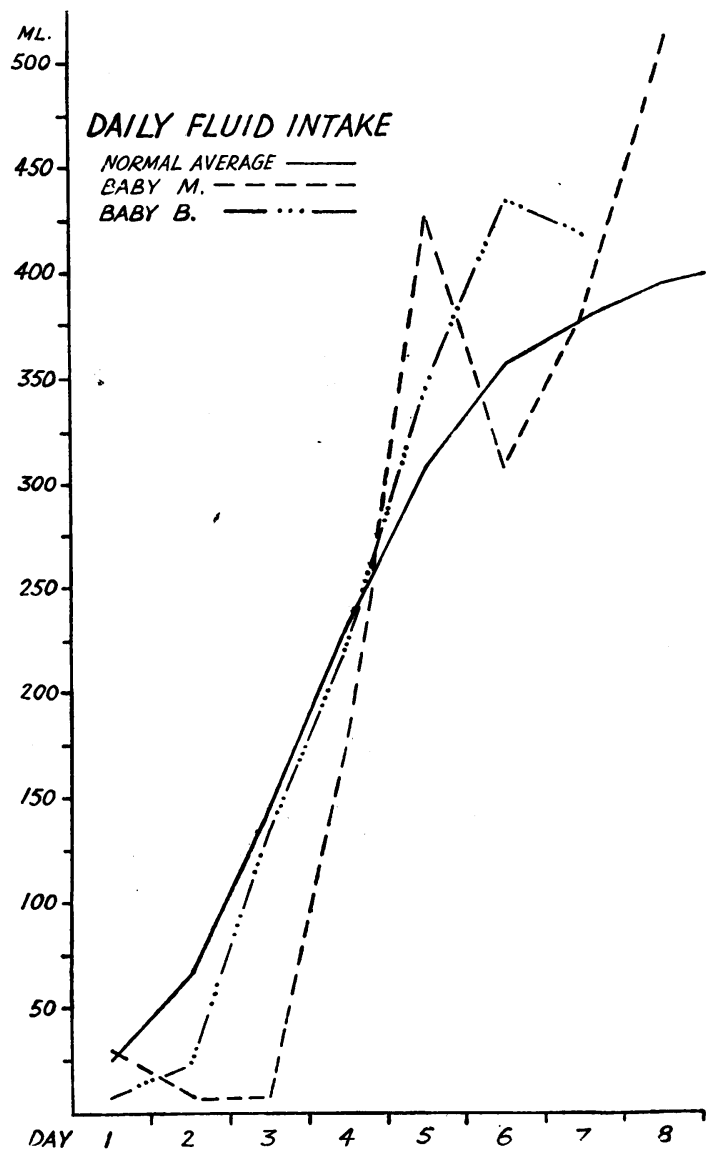

FIG. 3.-Daily fluid intake, babies $M$. and B. compared with normal average.

Grulee and Bonar (1921), who demonstrated that there is no relationship between the amount of the babies' weight loss and the incidence of pyrexia, nor between the amount of the fluid intake and the pyrexia.

In his investigation into the serum protein concentration in the newborn, Bakwin (1922) has shown that the occurrence of dehydration fever is related to an increasing concentration of serum protein which coincides with the so-called physiological weight loss. He has also demonstrated that the incidence of the fever is not related to the amount 
of the weight loss, and suggested that the level of the body water reserve at birth is an important determining factor.

In a later publication, Bakwin et al. (1922) demonstrate that the pyrexia is readily relieved by giving 30 to $40 \mathrm{ml}$. water per kilo of body weight by mouth. Examination of the urine in such cases of pyrexia in the neonatal period might well be



FIG. 4.-Daily output of urine, babies M. and B. compared with normal average.

expected to suggest some confirmation of Bakwin's thesis that the fever is the result of dehydration. A survey of the literature shows, however, that no investigator has published any such work to date. Grulee and Bonar (1921) state that no attempt was made to conduct a urinalysis. Because of this omission it is felt that the results of urinalysis in these two cases may be of some value.

The daily output of urine in both cases is below average, Table 3 , but as the daily fluid intake is also

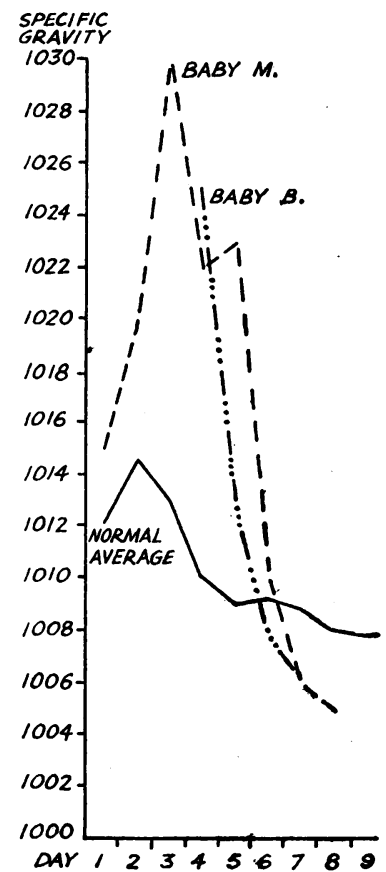

Fig. 5.-Specific gravity, babies $M$. and B. compared with normal average.

TABLB 5

BABY B. TIMES OF VOIDING AND VOLUMB OP URINE PASSED

\begin{tabular}{|c|c|c|c|c|c|c|c|c|c|}
\hline Day & Nil & & & & & & & & $\begin{array}{l}\text { Totals } \\
\text { Nil }\end{array}$ \\
\hline 2 & ml. $\begin{array}{r}11.15 \\
1: 5\end{array}$ & $\begin{array}{l}\text { a.m. } \\
9 \\
1.5\end{array}$ & & & & & & & 3 \\
\hline 3 & $\begin{array}{l}\text { Time un- } \\
\text { certain } \\
\text { ml. } 3 \cdot 5\end{array}$ & & & & & & & & 3.5 \\
\hline 4 & ml. $\begin{array}{c}\text { a.m. } \\
7.5\end{array}$ & $\begin{array}{l}\text { p.m. } \\
1 \\
1\end{array}$ & & & & & & & $8 \cdot 5$ \\
\hline 5 & $\mathrm{ml.} \quad \stackrel{5}{5.50}^{\text {p.m. }}$ & $28^{1.20}$ & & & & & & & 31 \\
\hline 6 & ml. 12 & 11.30 & $\begin{array}{l}\text { a.m. } \\
12.30 \\
4\end{array}$ & 2.15 & 11.50 & $\begin{array}{l}\text { p.m. } \\
3 \\
5\end{array}$ & 12.1 & $\begin{array}{l}4.10 \\
6\end{array}$ & 59 \\
\hline \multirow[t]{3}{*}{7} & $\begin{array}{ll} & \text { p.m. } \\
\text { ml. } & \mathbf{7}\end{array}$ & 11.50 & $\begin{array}{l}8.15 \\
6\end{array}$ & $\begin{array}{l}8.30 \\
9\end{array}$ & $\begin{array}{l}8.45 \\
4\end{array}$ & 11.45 & $\frac{\text { a.m. }}{12.30}$ & $\begin{array}{l}3.45 \\
5.5\end{array}$ & \\
\hline & ml. $\begin{array}{l}\text { a.m. } \\
7.5\end{array}$ & $\begin{array}{r}10 \\
5\end{array}$ & 10.15 & 11.25 & $\frac{p . m}{22.40}$ & 12.50 & $\begin{array}{l}1.30 \\
7\end{array}$ & 13.10 & \\
\hline & $\begin{array}{ll} & \text { p.m. } \\
& 3.50 \\
\text { ml. } & 6\end{array}$ & & & & & & & & 106 \\
\hline
\end{tabular}


below average until the fifth day, this is not surprising (fig. 3).

The relationship between the intake of fluid and the output of urine is such that a negative water balance is obvious in the case of Baby $\mathbf{M}$. during the first three days of life. In the case of Baby $B$.

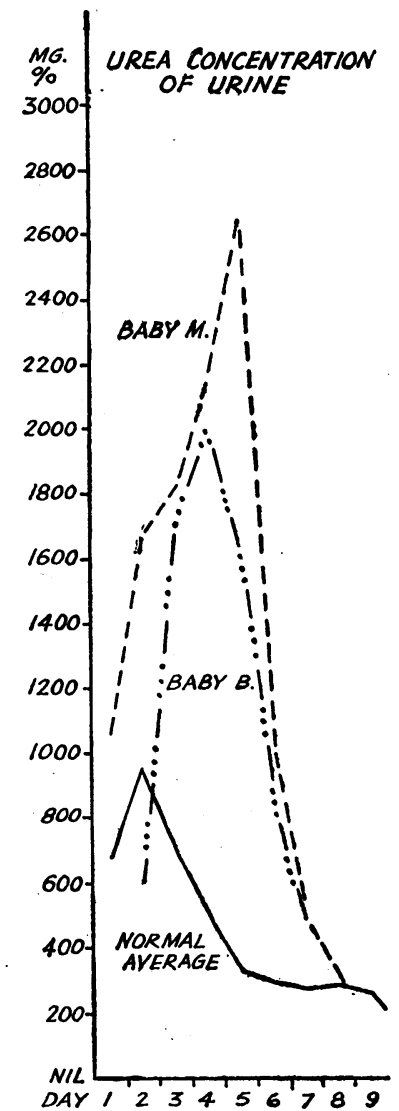

Fig. 6.-Urea concentration of urine, babies M. and B. compared with normal average.

the absence of the passage of urine during the first twenty-four-hour period is not to be considered abnormal, since it is not uncommon for a normal newborn infant to pass urine for the first time during its second twenty-four-hour period: while, rarely, the event may be delayed till the third twenty-four-hour period.

With the approach of pyrexia the urinary volume diminishes and the frequency of voiding may be decreased. In the two cases now under discussion the daily volume of the urine remained persistently below average throughout the period of observation (fig. 4).

Specific gravity. In keeping with the low volume of the renal output, the specific gravity of the urine is well above normal during the first five days in the case of Baby $M$. It is striking to note how renal concentrating power is called into action before the onset of pyrexia, how it increases pari-passu with the pyrexia, and how on the subsidence of the pyrexia it still follows a somewhat parallel course but is slower in its descent (fig. 1).

In the case of Baby B. it was not possible to demonstrate the increase in renal concentrating power by means of the specific gravity before the pyrexia, but the parallel though slower decline in the concentrating power of the kidney is well demonstrated (fig. 2). The wide difference between the specific gravity figures in these two cases and average figures obtained from apyrexial babies is well demonstrated in fig. 5 and in table 3 . It implies that the kidney in the newborn infant is capable of concentrating the urine to a much greater extent than is usually recognized.

Urea. The concentration of urea in the urine is increased from day to day in the first five days in

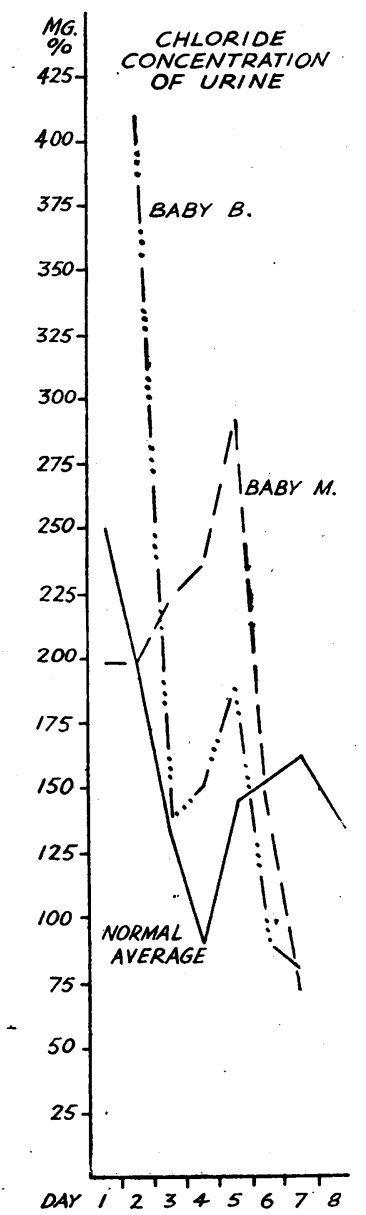

Fig. 7.-Chloride concentration of urine, babies M. and B. compared with normal average. 
both cases. The increase is much greater and more rapid than is found in normal apyrexial babies (fig. 6). The figures recorded are greater than any of the figures which I recorded in apyrexial babies (Thomson, 1944). The urea concentration figures follow a somewhat parallel course to the spicific

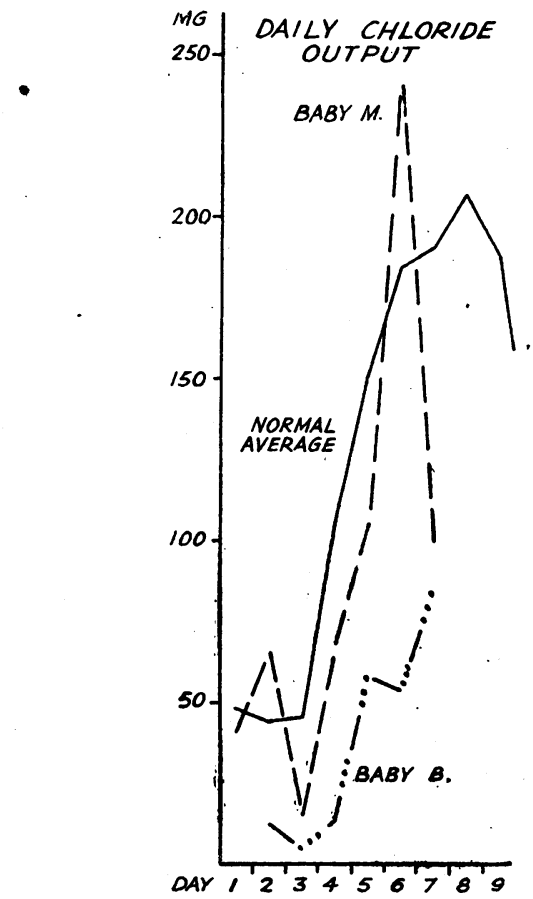

Fig. 8.-Daily chloride output, babies M. and B. compared with normal average.

gravity figures, the increase in concentration appearing before the onset of pyrexia and normal average figures not being reached till the eighth day.

Chlorides. In neither of the two cases now presented does the chloride concentration in the urine follow an average normal pattern (fig. 7). In the case of Baby' $M$. the normal fall occurring in the first four days is replaced by an increase which subsequently falls below normal. It bears the same relationship to the pyrexia as is seen in the case of the specific gravity and concentration of urea (fig. 1). Despite the increased chloride concentration, at no time does the total daily output of chloride greatly exceed the normal (fig. 8). The curve of the chloride concentration in the case of Baby B., after falling from the initial high figure of $410 \mathrm{mg}$. per cent.s approximates somewhat to that shown in the first instance. Excluding the initial high reading, the curve in this case, too, bears the same relationship to the pyrexia as does the specific gravity and urea concentration (fig. 2 ).

\section{Summary}

1. In two cases of dehydration fever in the newborn, the daily output of urine with its specific gravity, urea, and chloride concentration is recorded.

2. These observations are related to the time of onset and subsidence of the pyrexia.

3. The figures for the urinalysis are compared with those for normal average apyrexial newborn babies.

4. From the observations made it would appear that the kidney of the newborn infant is capable of concentrating the urine to a much greater extent than is generally recognized.

This investigation was carried out during the tenure of a Crichton Research Scholarship.

\section{REFERENCES}

Bakwin, H..(1922). Amer. J. Dis. Child., 24, 497. (1922). Ibid., p. 508.

- Morris, R. M. and Southworth, J. D. (1924). Ibid., 27, 578.

Balcar, J. O., Sansum, W. D. and Woodyatt, R. T. (1919). Arch. intern. Med., 24, 116.

Grulee, C. G. and Bonar, B. E. (1921). Amer. J. Dis. Child., 22, 44

Holt, L. E. (1895). Arch. Pediat., 12, 561.

Thomson, J. (1944). Arch. Dis. Childh., 19, 169. 